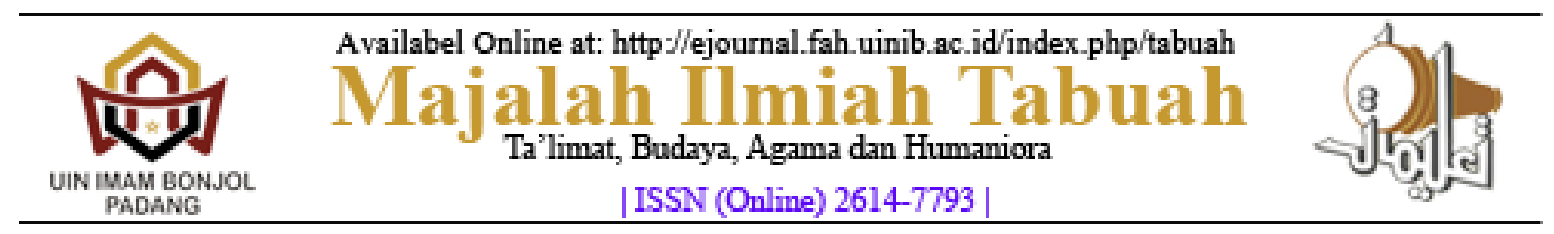

\title{
Perkembangan Madrasah Nizamiyah (Analisis Terhadap Lembaga Dan Kurikulum Pendidikan Islam)
}

\author{
Deprizon \\ Universitas Muhammadiyah Riau \\ email: deprizon@umri.ac.id \\ Alfurqan \\ Universitas Negeri Padang \\ email: alfurqan@fis.unp.ac.id \\ Ahmad Taufik Hidayat \\ UIN Imam Bonjol Padang \\ email: ahmadhidayat@uinib.ac.id
}

\begin{abstract}
In this research study, the authors describe the existence of educational institutions (madrasah Nizamiyah) and educational curricula in the Nizam Al-Mulk era. Nizam Al-Mulk with several of his madrasas had built a network of higher education institutions in his time, and he was the first to be able to do so. Even so, the Nizamiyah madrasa is not the first madrasa in the history of Islamic education. Because there have been many madrasas before the Nizam Al-Mulk era. The Nizamiyah madrasah learning system applies a classical learning system, in which a teacher stands in front of the classroom presenting lecture material. While the students sat and listened on the bench provided, then continued with dialogue (questions and answers) between the teacher and students. Furthermore, the madrasa curriculum in the Nizam Al-Mulk era was centered on the Qur'an, which included reading, memorizing and writing, Arabic literature, the history of the prophet Muhammad SAW, and counting, with an emphasis on the Shafi'i school and the Asy 'theological system. ariyah. Philosophy itself is not included as part of the curriculum at this time.
\end{abstract}

Keywords: Institutions, Islamic Education Curriculum, Madrasah Nizamiyah

\begin{abstract}
Abstrak
Dalam kajian penelitian ini, penulis menjelaskan gambaran tentang eksistensi lembaga pendidikan (madrasah Nizamiyah) dan kurikulum pendidikan di era Nizam Al-Mulk. Nizam Al-Mulk dengan beberapa madrasahnya telah membangun sebuah jaringan lembaga pendidikan tinggi pada masanya, dan ia adalah orang pertama yang mampu melakukan hal itu. Sekalipun demikian madrasah Nizamiyah bukanlah madrasah pertama yang ada dalam sejarah pendidikan Islam. Sebab telah terdapat banyak madrasah sebelum era Nizam Al-Mulk. Sistem belajar madrasah Nizamiyah menerapkan sistem belajar klasikal, yaitu seoang tenaga pengajar berdiri di depan ruang kelas menyajikan materi perkuliahan. Sementara para pelajar duduk dan mendengarkan diatas bangku yang disediakan, kemudian dilanjutkan dnegan dialog (soal jawab) antara pengajar dan siswa. Selanjutnya, kurikulum madrasah di era Nizam AlMulk ini berpusat pada Al-Qur'an, yang meliputi membaca, menghafal dan menulis, sastra arab, sejarah nabi Muhammad SAW, dan berhitung, dengan menitikberatkan pada mazhab Syafi'i dan sistem teologi Asy'ariyah. Ilmu filsafat sendiri tidak dimaskukkan sebagai bagian dalam kurikulum pada masa ini.
\end{abstract}

Kata Kunci: Lembaga, Kurikulum Pendidikan Islam, Madrasah Nizamiyah 


\section{PENDAHULUAN}

Pada pemerintahan Bani Saljuk khususnya dibawah penguasa Sultan Alp Arsalan, dikenal dengan usaha yang agung dalam pengembangan ilmu pengetahuan dan peradaban. Hal ini ditunjukkan dengan adanya langkah perkembangan lembaga pendidikan tinggi. Istilah lembaga pendidikan tinggi di sini tidak dapat disamakan dengan istilah lembgaa pendidikan tinggi sekarang. Akan tetapi merupakan istilah yang dipakai untuk mengelompokkan dalam jenjang pendidikan yaitu tingkat pendidikan dasar dan tingkat pendidikan tinggi. Upaya ini dipelopori oleh wazir Perdana Menteri Nizam Al-Mulk, seorang negarawan yang cakap dan terpercaya. Berkat kecakapannya ia menjabat sebagai perdana Menteri hingga pada sultan berikutnya ${ }^{1}$.

Nizam Al-Mulk berupaya menciptakan stabilitas negara dengan senantiasa bekerja sama dengan beberapa pihak. Salah satu yang dilakukannya adalah dengan mendirikan madrasah yang kemudian dinisbatkan kepada namanya yaitu madrasah Nizamiyah. Upaya ini pada gilirannya membawa Nizam Al-Mulk menjadi sangat populer, dikarenakan lewat jaringan madrasah yang ia bangun, ia mampu tampil menjadi sosok yang dicontoh oleh para penguasa dan bangsawan lain.

Istilah madrasah yang akan digunakan dalam pembahasan ini, tidaklah sama dengan istilah madrasah dalam kontek keindonesiaan sekarang, yang lazim dipakai untuk sebutan lembaga pendidikan dasar dan menengah Islam (MI, MTs, dan MA). Madrasah dalam pembahasan makalah ini adalah merujuk pada lembaga pendidikan tinggi yang secara luas berkembang di dunia Islam pra modern.

Meskipun merupakan lembaga pendidikan tinggi, namun madrsaah juga tidak dapat disamakan dengan Universitas. Masing-masing memiliki ciriciri yang berbeda, yaitu: Pertama, madrasah merujuk pada satu bangunan tempat kegiatan pendidikan tinggi berlangsung, sementara kata Universitas merujuk pada komunitas atau sekelompok sarjana dan mahasiswa. Kedua, madrasah bersifat individual dan personal dnegan kontrol otoritas yang lemah, smeentara universitas bersifat hirarkis dengan sistem kontrol yang jelas. Ketiga, izin mengajar (ijazah) pada madrasah diberikan oleh syaikh secara personal, sementara pada universitas dikeluarkan oleh komite secara kelembagaan (Hasan Asari, 2007). Oleh karena itu madrasah sebagai lembaga pendidikan tinggi dalam bahasan ini adalah merupakan wadah atau tempat pelaksanaan proses belajar mengajar

\footnotetext{
${ }^{1}$ Hasan Muarif Ambary, "Suplemen Ensiklopedi Islam," in Ensiklopedi Islam, 1996.

${ }^{2}$ Alfurqan Alfurqan, Zainurni Zein, and Abdul

Salam, "IMPLEMENTASI KHAZANAH SURAU
}

lanjutan bagi para siswa yang telah menyelesaikan pendidikan pada tingkat dasar.

Madrasah merupakan hasil evolusi lembaga pendidikan dari masjid-khan (asrama), lalu ke madrasah itu sendiri. Perkembangan ini menjadi suatu kebutuhan dimana masjid dan masjid khan tidak dapat lagi menampung para pelajar yang menuntut ilmu ${ }^{2}$.

Sementara Nizamiyah adalah sebutan bagi madrasah yang dinisbatkan kepada pendirinya pada tahun 1065-1067 yaitu Nizam Al-Mulk. Nama aslinya adalah Abu Ali Al-Hasan bin Ali Ishak AlTusi. Lahir di Tus Khurasan pada 10 April 1081 M, dan wafat di Shihna pada 14 Oktober 1092 M (Hasan Asari, 2007). Nizam Al-Mulk diangkat menjadi Perdana Menteri oleh Sultan Alp Arsalan menggantikan pejabat sebelumnya Ali Ahmad bin Syazan yang meninggal dunia.

Nizam Al- Mulk adalah seorang yang mencintai ilmu pengetahuan. Ia tampil sebagai Perdana Menteri yang menunjukkan kecakapannya dan menjadi negarawan yang terpercaya. Ia senantiasa menasihatkan sultan dalam upaya memelihara stabilitas negara. Bahkan sepeninggal Sultan Alp rsalan, ia umumkan bahwa Maliksyah sebagai putra mahkota yang akan menggantikan sultan. Ia juga sennatiasa menjalin hubungan yang baik dengan Khalifah Abbasiyah sebagai pemimpin tertinggi dunia Islam ketika itu, sehingga ia mendapat penghargaan dari khalifah Al-Qai'im dari Abbasiyah berupa gelar Qiwam Al-Din (pendukung agama) dan Radi Amir Al-Mukminin (yang meridhai dan pemimpin orang-orang beriman).

Ia dikenal sebagai Perdana Menteri yang berpaham Asy'ariyah dan mengusahakan penyebarannya melalui madrsah yang didirikannya. Usahanya mendirikan madrasah mendapat dukungan dari para ulama yang bermazhab Syafi'i, seperti: Imam Al Haramain Abu Ma'ali Al Juwaini dan Al Qusyairi (Ensiklopedi Islam: 43). Dua tokoh ulama tersebut adalah bagian dari beberapa ulama Asy'ariyah yang pada masa Sultan Tugril Beg dan wazir Al-Kunduri, mereka dikutuk melalui mimbarmimbar masjid karena dianggap memiliki paham berlianan, hingga mengasingkan diri.

Pada tahun 1091 M Nizam Al-Mulk menulis kitab Siyaset Name, buku mengenai politik yang berisi siasat pemerintahan, terdiri dari 50 bab nasihat yang digambarkan melalui anekdot sejarah. Kemudian ia tambahkan 11 bab tentang bahaya yang mengancam keutuhan Salajikan. Ia meninggal dunia pada ahun 1092 M, karena dibunuh oleh seorang

\footnotetext{
TERHADAP PENDIDIKAN ISLAM MODERN," TARBAWY : Indonesian Journal of Islamic Education, 2019, https://doi.org/10.17509/t.v6i2.20211.
} 
pasukan Hasyasyin (Hasyasyin adalah pasukan pembunuh pimpinan Hasan bin As Sabah yang menyamar sebagai Sufi, sehingga berhasil membunuh Nizam Al Mulk tahun 1092 M.), yang bertujuan menghidupkan kembali Dinasti Fatimiah ${ }^{3}$.

\section{HASIL DAN PEMBAHASAN Madrasah Nizamiyah}

Madrasah Nizamiyah adalah merupakan lembaga pendidikan tinggi yang diambil dari nama pendirinya yaitu Nizam Al-Mulk. Madrasah yang pertama kali didirikan oleh Nizam Al-Mulk di Nisyapur pada tahun $1050 \mathrm{M}$, kemudian menyusul madrasah di Baghdad pada tahun 1065-1067 M. Lalu di kota-kota lain yaitu di Basrah, isfahan, Herat, Baikh dan Mosul. Semua madrash ini dinamai dengan madrasah Nizamiyah. Tentang madrasah Nizamiyah yang diidrikan di beberapa kota ini, penulis tidak menemukan informasi kapan tahun didirikannya.

Nizam Al- Mulk dengan beberapa madrasahnya tersebut membangun sebuah jaringan lembaga pendidikan tinggi pada masanya, dan ia adalah orang pertama yang mampu melakukan hal itu. Sekalipun demikian Madrasah Nizamiyah bukanlah madrasah pertama yang ada dalam sejarah pendidikan Islam. Sebab dalam sumber lain, menyebutkan bahwa telah terdapat banyak madrasah sebelum era Nizam AlMulk. Hal ini terjadi barangkali karena ia memandang eksistensi madrasah itu menjadi sebuah institusi sudah ada pada waktu itu ${ }^{4}$.

Madrasah Nizamiyah menjadi populer salah satu sebabnya adalah berkat popularitas Perdana Menteri Nizam Al-Mulk, yang mendominasi pendirian madrasah-madrasah tersebut. Pada gilirannya melalui madrsaah-madrasah itu ia ngin menghidupkan kembali ajaran ahli sunnah di tengah-tengah masyarakat, sekaligus berguna bagi upaya untuk menjaga stabilitas negara.

Latar belakang berdirinya Madrasah Nizamiyah dapat diungkapkan beberapa hal sebagai berikut:

1. Dari sudut pendidikan

Nizam Al-Mulk adalah seorang yang sangat mengagungkan ilmu pengetahuan dan pendidikan, sehingga jika ia memperhatikan berkembangnya institusi pendidikan adalah sesuatu yang wajar dan penting. Disamping itu kehadiran madrsah memang dibutuhkan untuk melengkapi berbagai kelemahan sistem pendidikan di mesjid.

2. Dari sudut konflik keagamaan.

\footnotetext{
${ }^{3}$ Ana A and Faliqul J.F, "NIZAM AL-MULK, PENGEMBANG SISTEM PENDIDIKAN KELAS DUNIA," CSSMoRA, 2013.

${ }^{4}$ Wikipedia.org, "Nizam Al-Mulk," Wikipedia.org, 2013.
}

Pada saat Nizam Al-Mulk mula-mula diangkat menjadi perdana menteri, para penganut mazhab Syafi'i yang beraliran Asy'ariyah, merasa terusir dan teraniaya. Hal ini adalah merupakan warisan kebijkan pendahulunya, wazir Al-Kunduri yang bermazhab hanafi dan pendukung aliran Mu'tazilah. Sebagai seorang Syafi'iyah, Nizam memperbaiki dan mengangkat kembali citra kehormatan para ulama Syafi'iyah-Asy'ariyah. Dan memang dibangunnya madrasah adalah untuk diperuntukkan bagi para penganut faham yang sama ${ }^{5}$.

3. Dari sudut pegawai pemerintahan

Sebagai seorang wazir, Nizam Al-Mulk harus memperhatikan sistem administrasi negara yang baik. Untuk itu, ia bangun suatu sistem administrasi sentral di Baghdad yang kokoh dnegan kendali yang kuat dan berpengaruh. Dalam hal ini madrasah membantunya dnegan mengeluarkan lulusan yang siap bekerja untuk Nizam Al-Mulk, sebagai khatib (sekretaris), qadli (hakim) dan sebagainya.

4. Dari sudut politik

Jaringan madrash yang dibangun Nizam AlMulk secara politis tidak dapat dipisahkan dari perannya sebagai wazir. Menggunakan madrasah sebagai alat untuk melindungi kelompok Syafi'iyyah yang bgeraliran Asy'ariyah yang membentuk suatu kesatuan yang medukung kebijakannya. Para ulama dididik dan mengajar pada lembaga yang dikontrol oleh Nizam Al-Mulk melalui otoritasnya dalam mengangkat staf.

Berdasarkan beberapa sudut latar belakang diatas, terdapat beberapa faktor yang mengiringi munculnya madrasah Nizamiyah sebagai fenomena sejarah. Tidak hanya sekedar faktor pendidikan dan agama saja, akan tetapi faktor politik, sosial juga meliputinya.

Keberhasilan Nizam Al-Mulk membangun jaringan madrasah, pada perkembangan berikutnya menjadi contoh bagi para penguasa dan bangsawan lain untuk mengikuti langkahnya, yaitu dengan membangun berbagai madrasah dalam rangka mendukung bahkan sebagai alat dalam penyebaran ajarannya.

Bermula dari Irak, madrasah populer pada masa Nizam Al-Mulk. Kemudia di Mesir, Syiria, Palestina, yang disebabkan oleh Nur al-Din (w. Th $1174 \mathrm{M}$ ) dan Sholahuddin al-Ayyubi (w. 1193 M) ${ }^{6}$. Hal ini menunjukkan bahwa madrasah dengan sendirinya menyebar dan populer di kalangan umat dari masa ke

\footnotetext{
${ }^{5} \mathrm{~A}$ and J.F, "NIZAM AL-MULK, PENGEMBANG SISTEM PENDIDIKAN KELAS DUNIA."

${ }^{6}$ Abdul Fattah, "Studi Analitis Dimensi Sacifact

Pendidikan Islam Pada Masa Kejayaannya (7501258 M)," Ulumuna, 2008, https://doi.org/10.20414/ujis.v12i1.388.
} 
masa hingga hampir tiap kota tidak ada yang tanpa madrasah.

\section{Madrasah Nizamiyah di Nishapur}

Madrasah ini dibangun oleh Nizam Al-Mulk pada tahun $1050 \mathrm{M}$ untuk al-Juwaini. Al-Juwaini menjadi mudaris (guru besar) pada madrasah ini selama lebih dari 3 dekade, yang berakhir dengan meninggalnya pada tahun $108^{7}$.

Secara fisik madrasah ini terdiri dari 3 bagian inti, yaitu: sebuah gedung madrasah, sebuah mesjid, dan sebuah perpustakaan. Beberapa staf yang dimiliki adalah: seorang guru besar yang bertanggungjawab dalam pelaksnaan pengajaran, seorang ahli Qur'an, seorang ahli hadits dan seorang pustakawan. Madrasah ini dilengkapi dengan fasilitas tempat tinggal bagi staf dan bagi para mahasiswanya.

\section{Madrasah Nizamiyah di Baghdad}

Dari sekian banyak madrasah yang dibangun oleh Nizam Al-Mulk, madrasah di Baghdad adalah yang paling terkenal. Dibangun pada tahun $1065 \mathrm{M}$. Hal-hal penitng yang bersifat prinsipil dituangkan dalam dokumen piagam pendirian madrasah. Isi dokumen tersebut adalah sebagai berikut:

a. Nizamiyah merupakan wakaf yang disediakan untuk kepentingan penganut mazhab syafi'i.

b. Harta benda yang diwakafkan pada Nizamiyah adalah untuk kepentingan penganut mazhab Syafi'i.

c. Pejabat utama Nizamiyah harus penganut mazhab syafi'i, hal ini mencakup mudaris, wa'idh atau asisten, dan pustakawan.

d. Nizamiyah harus mempunyai seorang tenaga pengajar bidang Al-Qur'an dan seorang pengajar Bahsa Arab.

e. Setiap staf menerima bagian tertentu dari penghasilan yang diperoleh dari harta wakaf ${ }^{8}$.

Para guru besar yang pernah menjadi staf di madrasah ini adalah: Abu Ishak al-syirozi (w. 1083 M0, Abu Nashr al-Shabbagh (w. 1084 M), Abu alQasim al-Alawy (w. 1089 M), Abu Abdullah AlThabari (w. 1101 M), Abu Hamid Al-Ghazali (w. $1111 \mathrm{M})$. Sebagai pustakawan adalah Abu Zakaria alTabrizi (w. 1109 M), dan sebagai asisten adalah Abu Bakar al-Faruqi (w. $1085 \mathrm{M}$ ) dan Ibnu al- Khusairi (w. $1077 \mathrm{M}$ ) ${ }^{9}$.

\footnotetext{
${ }^{7}$ Wikipedia.org, "Nizam Al-Mulk."

${ }^{8}$ Wikipedia.org.

${ }^{9}$ Susan L Douglass and Munir A Shaikh, "Defining Islamic Education: Differentiation and Applications," Current Issues in Comparative Education, 2004.

${ }^{10}$ Frans H Doppen, "Education, Citizenship and Social Justice," Social Justice A Journal Of Crime Conflict And World Order, 2010.
}

Dua madrasah diatas sebagai gambaran dari madrasah Nizamiyah lain yang tersebar di berbagai kota. Namun demikian umumnya madrasahmadrasah itu berada dalam satu sistem dan satu tujuan.

\section{Kurikulum dan Materi Pendidikan Madrasah Nizamiyah}

Institusi pendidikan yang dominan pada masa Dinasti Saljuk adalah madrasah. Pendirian madrasah pada sat itu tidak terlepas dari kepentingan politik yang mengitarinya. Madrasah oleh Dinasti Saljuk dijadikan alat propaganda tandingan untuk menekan pengaruh aliran Syi'i dan menyebarluaskan aliran Sunni di tengah-tengah masyarakat diseluruh wilayah kekuasan Dinasti Saljuk dengan cara memasukkan materi keagamaan versi Sunni ke dalam kurikulum Madrasah Nizamiyah. Sehinggga cukup beralasan mengapa materi keagamaan cukup mendominasi dalam kurikulum pendidikan madrasah sat itu. ${ }^{10}$

Madrasah Nizamiyah menerapkan sistem belajar klasikal, yaitu seorang tenaga pengajar berdiri di depan ruang kelas menyajikan materi perkuliahan. Sementara para pelajar duduk dan mendengarkan diatas bangku yang disediakan. Kemudian dilanjutkan dnegan dialog (soal jawab) antara pengajar dam siswa mengenai materi yang disajikan dalam suasana semangat keilmuan yang tinggi. Dengan demikian dapat dikatakan bahwa madrasah Nizamiyah adalah merupakan madrasah pertama yang menerapkan sistem pengelolaan yang baik dan teratur.

Kurikulumnya berpusat pada Al-Qur'an, yang meliputi membaca, menghafal dan menulis, sastra Arab, sejarah Nabi SAW, dan berhitung, dengan menitikberatkan pada mazhab syafi'i dan sistem teologi Asy'ariyah. Namun tidak memasukkan filsafat sebagai bagin dari kurikulum ${ }^{11}$. Hal ini diantaranya disebabkan oleh Nizam Al-Mulk bukanlah orang yang membela ilmu filsafat yang bukan pula orang yang membantu pembebasan filsafat.

Lain dari pada itu yang nampaknya juga menjadi sebab kedua adalah bahwa di dalam dokumen piagam Nizamiyah tidak disebutkan adanya pengajaran kalam tau filsafat. Dengan demikian, dapat diasumsikan bahwa madrasah Nizamiyah adalah berafiliasi kepada pengajaran fiqh. Asumsi ini

${ }^{11} \mathrm{H}$ Alfurqan, A., \& Harmonedi, "Pandangan Islam Terhadap Manusia: Terminologi Manusia Dan

Konsep Fitrah Serta Implikasinya Dengan

Pendidikan," Journal of Educational Studies 2, no. 2 (2017): 129-44, http://dx.doi.org/10.30983/educative.v2i2.468. 
diperkuat dengan ditariknya para ulama fiqh dalam pengajaran di madrasah tersebut.

Status pengajar di madrasah Nizamiyah ditetapkan berdasarkan pengangkatan dari khalifah dan bertugas untuk masa tertentu. Untuk menunjukkan betapa madrasah ini mencoba mengembangkan diri untuk menjadi suatu lembaga pendidikan yang sesuai dengan tuntutan zaman, Nizam Al-Mulk menetapkan untuk memberi gaji setiap bulan bagi tiap pengajar di madrasah tersebut. Namun kebijakan ini belum bisa diterima oleh para pengajar, karena dipandang sebagai suatu gagasan yang terlalu maju. Mereka lebih suka tanpa gaji, tetapi kesejahteraan mereka terjamin ${ }^{12}$. Nizam AlMulk telah menetapkan anggaran belanja untuk seluruh madrasah Nizamiyah sebanyak 600.000 dinar dalam setahun. Dari sejumlah anggaran itu sepenuhnya yaitu 60.000 dinar khusus diperuntukkan bagi madrasah Nizamiyah di Baghdad.

Hal ini menunjukkan, bahwa pengelolaan anggaran belanja madrasah pada saat itu telah dapat direalisasikan dengan baik. Sekalipun untuk menelusuri lebih jauh tentang anggaran madrasah ini, penulis tidak menemukan sumber yang konkrit, namun paling tidak diperoleh gambaran bahwa pengelolaan madrasah pada saat itu telah maju demikian pesatnya.

Dalam proses belajar mengajar, metode pendidikan atau pengajaran merupakan salah satu aspek yang sangat penting guna mentransfer pengetahuan atau kebudayaan dari guru kepada muridnya. Pada masa Abbasiyah, metode pendidikan atau pengajaran yang digunakan dapat dikelompokkan menjadi tiga macam yaitu ${ }^{13}$ :

1. Metode lisan, terdiri dari dikte (imla'), ceramah (al-sama'), bacaan (qira'ah), dan diskusi. Metode imla' adalah metode untuk menyampaikan pengetahuan yang dianggap baik dan aman karena pelajar mempunyai catatan. Jika daya ingat pelajar tidak kuat, catatan bisa membantunya. Metode ceramah disebut juga metode al-sama', sebab dalam metode ceramah, guru membacakan bukunya atau menjelaskan isi buku dengan hafalan, sedangkan murid mendengarkannya. Pada saat tertentu guru berhenti dan memberi kesempatan kepada pelajar untuk menulis dan bertanya. Metode qira'ah atau membaca, biasanya digunakan untuk belajar membaca. Sedangkan diskusi, banyak digunakan

\footnotetext{
${ }^{12}$ Wikipedia.org, "Nizam Al-Mulk."

${ }^{13}$ Solichin Mohammad Muchlis, "Pendidikan Islam

Klasik: Telaah Sosio-Historis Pengembangan

Kurikulum Pendidikan Islam Masa Awal Sampai

Masa Pertengahan," Tadris, 2008.
}

dalam pengajaran ilmu-ilmu yang bersifat filosofis dan fiqh.

2. Metode hafalan, sangat ditekankan dalam pendidikan Islam karena seorang pelajar akan mengkontekstualisasi pelajaran yang dihafalnya sehingga dalam diskusi atau perdebatan dia dapat merespon, mematahkan lawan, atau memunculkan sesuatu yang baru ketika dalam perdebatan atau diskusi.

3. Metode tulisan, Metode ini perlu untuk mengkopi karya-karya ulama, karena pada saat itu tidak ada mesin cetak. Dalam pengkopian buku-buku, terjadi proses intelektualisasi sehingga tingkat penguasaan ilmu seseorang semakin meningkat, dan akhirnya menimbulkan sistem ta'liqah terhadap karya-karya ulama ${ }^{14}$.

Adapun materi yang disampaikan dalam pengajaran terdiri dari materi pelajaran yang bersifat wajib dan pilihan. Materi pelajaran yang bersifat wajib antara lain:

1. Al-Qur'an

2. Shalat

3. Doa

4. Ilmu Nahwu dan bahasa Arab (pokokpokoknya saja)

5. Membaca dan menulis

Sedangkan materi pelajaran yang bersifat ikhtiyari (pilihan) adalah sebagai berikut:

1. Berhitung

2. Semua Ilmu Nahwu dan bahasa arab

3. Syair-syair dan

4. Riwayat atau tarikh Arab. ${ }^{15}$

Bukti dominasi ilmu-ilmu keagamaan dalam madrasah juga terbukti dari dokumen waqaf Madrasah Nizamiyah, yaitu:

1. Nizamiyah merupakan wakaf yang diediakan untuk kepentingan penganut madhhab Syafi' $i$ dalam Fiqh dan Ushul Fiqh.

2. Harta benda yang diwakafkan kepada Nizamiyah untuk kepentingan penganut madhhab Syafi'i dalam Fiqh dan Ushul Fiqh.

3. Pejabat-pejabat utama Nizamiyah harus bermadhhab Syafi'i dalam Fiqh dan Ushul Fiqh, ini mencakup Mudarris, Wa'idh dan pustakawan.

4. Nizamiyah harus mempunyai seorang tenaga pengajar bidang kajian Al- Qur'an.

5. Nizamiyah harus mempunyai seorang tenaga pengajar bidang pengajar Bahasa Arab.

${ }^{14}$ Serli Mahroes, "Kebangkitan Pendidikan Bani Abbasiyah Perspektif Sejarah Pendidikan Islam," Jurnal TARBIYA, 2015.

${ }^{15}$ Wan Othman Mohd Roslan, Mohd Nor, Wan Mohd Tarmizi, "Sejarah Dan Perkembangan Pendidikan Islam," Jurnal At-Ta'dib, 2011, https://doi.org/10.1007/s13398-014-0173-7.2. 
6. Setiap staf menerima bagian tertentu dari penghasilan yang diperoleh dari harta wakaf Nizamiyah. ${ }^{16}$

Mengapa ilmu-ilmu kealaman (fisika, kimia, astronomi) dan kedokteran tidak dimasukkan ke dalam kurikulum pendidikan madrasah Nizamiyah. Hal ini dapat disinyalir karena motif utama pendirian madrasah Nizamiyah adalah politik dan ideologi penguasa pada pemerintahan Dinasti Saljuk.

Menurut Mahmud Yunus, rencana pengajaran di Madrasah Nizamiyah pada saat itu belum diketahui dengan jelas, namun bisa dikatakan bahwa kurikulum Madrasah Nizamiyah pada saat itu didominasi oleh ilmu-ilmu keagamaan dan ilmu-ilmu syari'ah. Sebagai bukti adalah:

1. Tidak ada seorangpun ahli sejarah yang mengatakan bahwa diantara materiyang diajarkan di Madrasah Nizamiyah adalah ilmu kedokteran, ilmu falak dan ilmu pasti. Tetapi mereka hanya menyebutkan bahwa diantara materi pelajarannya adalah nahwu, ilmu kalam dan ilmu fiqh.

2. Guru-guru yang mengajar di Madrasah Nizamiyah adalah ulama-ulama syari'ah seperti: Abu Ishaq al-Syarazi, Al-Qazwaini, Ibn Al-Jauzi dan lainlain. Tidak dikatakan bahwa di sana ada guru filsafat. Maka Madrasah Nizamiyah bukan madrasah filsafat tapi madrasah syari'ah.

3. Pendiri Madrasah Nizamiyah bukan orang pembela filsafat dan bukan pula orang yang membentu pembebasan filsafat.

4. Zaman berdirinya Madrasah Nizamiyah bukanlah zaman keemasan filsafat melainkan penindasan terhadap filsafat. ${ }^{17}$

Karena Madrasah Nizamiyah didirikan oleh penguasa atau pemerintah dengan berbagai kepentingan politik yang mengitarinya maka mau tidak mau kontrol atau dominasi pemerintah cukup kuat terhadap perjalanan dan proses pendidikan Madrasah Nizamiyah. Salah satunya adalah dalam menentuan kurikulum dan staf pengajar adalah guru Madrasah Nizamiyah. Guru-guru yang dtunjuk sendiri tidak sembarangan, mereka harus menganut aliran keagamaan yang sesuai dengan aliran keagamaan yang dianut oleh pemerintah yakni aliran Sunni. Begitu juga mengenai kurikulumnya.

Dominasi atau kontrol pemerintahan Dinasti Saljuk terhadap aktivitas pendidikan Madrasah Nizamiyah tidak hanya sebatas penentuan kurikulum dan staf pengajar, tetapi anggaran biaya dan pengangkatan staf lainnya juga menjadi perhatian yang sangat penting dalam menentukan mutu pendidikan. Ada beberapa hal yang tentunya dijadikan rujukan dari sejarah perkembangan

\footnotetext{
${ }^{16} \mathrm{~A}$ and J.F, "NIZAM AL-MULK, PENGEMBANG SISTEM PENDIDIKAN KELAS DUNIA."

${ }^{17} \mathrm{~A}$ and J.F.
}

Madrasah Nizamiyah dalam mencermati sekaligus mengaplikasikan sistem pendidikan dewasa ini antara lain:

1. Madrasah sebagai institusi pendidikan Islam dijadikan sebagai sarana atau wadah dalam menghidupkan madhhab Sunni dan paham Asy'ariyah.

2. Madrasah sebagai institusi pendidikan Islam dijadikan sebagai tempat untuk mengembangkan ilmu-ilmu Islam antara lain: ilmu Fiqh, Al-Qur'an dan Tafsir, Hadith dan Ilmu Hadith, Nahwu, Sharaf, bahasa Arab dan kesusastraan.

3. Madrasah sebagai institusi pendidikan Islam dijadikan sebagai panjang tangan untuk mempertahankan kekuasaan dan pergumulan pemikiran keagamaan. Sehingga banyak Madrasah Nizamiyah didirikan diberbagai kota, seperti: kota Balkh, Nisabur, Isfahan, Mosul, Basra, Tibrisan dan lain sebagainya.

4. Nizam al-Mulk dalam mengelola pendidikan baik sebagai pencetus ide pertama berdirinya, sekaligus sebagai bagian dari pemerintahan pada saat itu, selalu menunjukkan kesungguhannya. Hal ini tercermin dalam menyisihkan waktunya untuk memantau secara langsung proses pendidikan dengan mengadakan kunjungan-kunjungan ke berbagai Madrasah Nizamiyah diberbagai kota. Bahkan ikut terlibat dan menyimak kuliah-kuliah yang diberikan, dan kadangkadang juga ikut memberikan sumbangan pemikiran di depan para pelajar di madrasah tersebut. ${ }^{18}$

5. Madrasah sebagai institusi pendidikan Islam mengajarkan al-Qur'an; membaca dan menulis (sebagai pusat kurikulum), sastra Arab, Sejarah Nabi SAW dan berhitung serta menitikberatkan pada madhhab Syafi'i dan tidak lupa juga ideologi Asy'ariyah. Tenaga pengajar selalu berdiri di depan ruang kelas menyajikan materi-materi kuliah, sementara pelajar mendengarkan dengan khidmat dan mencatat. Selanjutnya diadakan dialog antara guru dan murid terkait dengan materi yang dibahas.

6. Status para pengajar pengangkatannya ditentukan oleh pemerintah.

7. Keterlibatan pemerintah tidak hanya sebatas perhatian saja, namun juga telah menyediakan dana yang cukup besar untuk keperluan fisik dan non fisik (beasiswa bagi

${ }^{18}$ Entus Riyadhy Ahmad, "Madrasah Nizhamiyah Pengaruhnya Terhadap Perkembangan Pendidikan Islam Dan Aktivitas Ortodok Sunni," Tarbiya, 2015. 
siswa dan uang pensiun bagi tenaga pengajar).

8. Proses pendirian Madrasah Nizamiyah telah mendapat dukungan dari berbagai pihak; pemerintah, ulama-ulama dan masyarakat. Hal ini menunjukkan bahwa Madrasah Nizamiyah merupakan kemauan dan keinginan bersama. Disamping itu Madrasah Nizamiyah dijadikan sebagai cermin dalam mencermati gambaran kondisi sosial masyarakat saat itu.

\section{Analisa Sejarah}

Dari pemaparan sejarah pertumbuhan dan perkembangan madrasah Nizamiyah diatas, terdapat beberapa hal yang perlu di garisbawahi sebagai suatu analisa kesejarahan. Dari sisi latar belakang berdirinya madrasah, selain dari beberapa faktor yang telah disebutkan terdahulu, terdapat juga faktor lain yang cukup dominan menyertai perkembangannya. Yaitu; sosok Nizam Al-Mulk yang berpendidikan dan gemar terhadap ilmu pengetahuan serta memiliki perhatian yang sungguh-sungguh terhadap lembaga pendidika, merupakan faktor intern personal yang perlu dikedepankan. Apalagi peluang ini di dukung oleh posisinya sebagai Perdana Menteri dan pada gilirannya madrasah diakui oleh negara.

Disisi lain yang perlu diungkapkan adalah adanya kecenderungan masyarakat untuk mengangkat supremasi syari'ah sebagai bagian yang dipentingkan. Sosok Nizam Al-Mulk yang bermazhab Syafi'i dan para sultan yang menganut aliran Asy'ariyah, sejalan dengan kehendak masyarakat. Sebab dari pengalaman penguasa sebelumnya, masyarakat merasa mendapat perlakuan yang tidak adil dan bahkan sebagian merasa teraniaya, karena berlainan mazhab dan faham dengan penguasa. Maka melalui madrasah upaya sosialisasi ajaran Syafi'iyah Asy'ariyah ini dapat dikembangkan.

Hal berikut yang menjadikan madrasah Nizamiyah berjaya adalah karena mendapatkan pengakuan dari negara yang bersifat saling menguntungkan. Penguasa berlindung dibalik madrasah yang dijadikan sebagai alat untuk sosialisasi ajaran maupun kebijakan politiknya. Sementara madrasah mendapatlan anggaran belanja yang cukup memadai untuk operasionalisasi dan pengembangannya.

Berdasarkan analisa diatas. Penulis berpendapat, bahwa untuk kemajuan suatu lembaga pendidikan, perlu dicarikan solusi kritis dalam pengembangannya. Tidak saja dari sudut kepentingan pendidikan, akan tetapi juga perlu dicermati dari sudur kerjasama dengan pemerintah. Kenudian dilihat juga arah kecenderungan masyarakat yang mensikapi adanya lembaga madrasah tersebut. Serta yang tidak kalah pentingnya menghindarkan lembaga dari upaya pemanfaatan sesaat oleh kepentingan tertentu dalam masyarakat. Dengan demikian, diharapkan yang ada sekarang paling tidak dapat mengambil nilai-nilai positif dari kebesaran sejarah perjalanan madrasah Nizamiyah.

\section{KESIMPULAN}

Madrasah Nizamiyah adalah merupakan lembaga pendidikan tinggi yang diambil dari nama pendirinya yaitu Nisam Al-Mulk. Madrasah yang pertama kali didirikan oleh Nizam Al-Mulk di Nisyafur pada tahun $1050 \mathrm{M}$, kemudian menyusul madrasah di Baghdad pada tahun 1065-1067 M. Lalu dikota-kota lain yaitu di Basrah, Isfahan, Herat, Baikh dan Mosul. Semua madrasah ini dinamai dengan madrasah Nizamiyah.

Nizam al-Mulk dnegan beberapa madrasahnya tersebut membangun sebuah lembaga jaringan pendidikan tinggi padamasanya, dan ia adalah orang pertama yang mampu melakukan hal itu. Sekalipun demikian madrasah Nizamiyah bukanlah madrasah pertama yang ada dalam sejarah pendidikan Islam. Sebab telah terdapat banyak madrasah sebelum era Nizam Al-Mulk. Hal ini terjadi barangkali karena ia memandang eksistensi madrasah itu menjadi sebuah institusi sudah ada pada waktu itu.

Madrasah Nizamiyah menerapkan sistem belajar klasikal, yaitu seorang tenaga pengajar beridiri didepan ruang kelas menyajikan materi perkuliahan. Sementara para pelajar duduk dan mendengarkan diatas bangku yang disediakan. Kemudian dilanjutkan dengan dialog 9soal jawab) antara pengajar dan siswa mengenai materi yang disajikan dalam suasana semangat keilmuan yang tinggi. Dengan semikian dapat dikatakan bahwa madrasah Nizamiyah adalah perupakan madrasah pertama yang menerapkan sistem pengelolaan yang baik dan teratur.

Kurikulumnya berpusat pada Al-Qur'an, yang meliputi membaca, menghapal dan menulis, sastra arab, sejarah Nabi SAW, dan berhitung dengan menitikberatkan pada mazhab Syafi'i dan sistem teologi Asy'ariyah. Namun tidak memasukkan filsafat sebagai bagian dari kurikulum. Hal ini diantaranya disebabkan oleh Nizam Al-Mulk bukanlah orang yang membela ilmu filsafat dan bukan pula orang yang membantu pembebasan filsafat. Adapun faktor yang mengiringi munculnya madrasah Nizamiyah sebagai salah satu fenomena dalam sejarah, tidak hanya sekedar faktor pendidikan dan agama saja, akan tetapi juga faktor politik, termasuk faktor sosial juga meliputinya. 


\section{DAFTAR PUSTAKA}

A, Ana, and Faliqul J.F. "NIZAM AL-MULK, PENGEMBANG SISTEM PENDIDIKAN KELAS DUNIA." CSSMoRA, 2013.

Ahmad, Entus Riyadhy. "Madrasah Nizhamiyah Pengaruhnya Terhadap Perkembangan Pendidikan Islam Dan Aktivitas Ortodok Sunni." Tarbiya, 2015.

Alfurqan, A., \& Harmonedi, H. "Pandangan Islam Terhadap Manusia: Terminologi Manusia Dan Konsep Fitrah Serta Implikasinya Dengan Pendidikan." Journal of Educational Studies 2, no. 2 (2017): 129-44. http://dx.doi.org/10.30983/educative.v2i2.46 8.

Alfurqan, Alfurqan, Zainurni Zein, and Abdul

Salam. "IMPLEMENTASI KHAZANAH

SURAU TERHADAP PENDIDIKAN

ISLAM MODERN." TARBAWY :

Indonesian Journal of Islamic Education, 2019. https://doi.org/10.17509/t.v6i2.20211.

Doppen, Frans H. "Education, Citizenship and Social Justice." Social Justice A Journal Of Crime Conflict And World Order, 2010.

Douglass, Susan L, and Munir A Shaikh. "Defining Islamic Education: Differentiation and Applications." Current Issues in Comparative Education, 2004.

Fattah, Abdul. "Studi Analitis Dimensi Sacifact Pendidikan Islam Pada Masa Kejayaannya (750-1258 M)." Ulumuna, 2008. https://doi.org/10.20414/ujis.v12i1.388.

Hasan Muarif Ambary. "Suplemen Ensiklopedi Islam." In Ensiklopedi Islam, 1996.

Mahroes, Serli. "Kebangkitan Pendidikan Bani Abbasiyah Perspektif Sejarah Pendidikan Islam.” Jurnal TARBIYA, 2015.

Mohammad Muchlis, Solichin. "Pendidikan Islam Klasik: Telaah Sosio-Historis Pengembangan Kurikulum Pendidikan Islam Masa Awal Sampai Masa Pertengahan.” Tadris, 2008.

Mohd Roslan, Mohd Nor, Wan Mohd Tarmizi, Wan Othman. "Sejarah Dan Perkembangan Pendidikan Islam." Jurnal At-Ta'dib, 2011. https://doi.org/10.1007/s13398-014-01737.2.

Wikipedia.org. "Nizam Al-Mulk." Wikipedia.org, 2013. 